\title{
Desarticulaciones (2010) / En breve cárcel (1981). Entre la escritura y la vida: Sylvia Molloy, las letras contaminadas de una crítica lateral ${ }^{1}$
}

\author{
ELEONORA CRÓQUER PEDRÓN Universidad Simón Bolívar, Venezuela \\ ORCID 0000-0002-0811-6126 \\ ecroquer@usb.ve
}

\section{Resumen}

En torno a Desarticulaciones (2010) y En breve cárcel (1981) de Sylvia Molloy, este artículo se concentra en el anudamiento entre escritura y vida que hace a las letras contaminadas de la autora, la «verdad» subjetiva que comprometen y el saber entre semiótico y analítico que incorporan acerca del vínculo entre experiencia, subjetividad y lenguaje. Por encima de las categorías estancas de crítica y ficción, entre las cuales la vida trama una relación de vasos comunicantes, y más allá del trazo autobiográfico que nunca se sintetiza en una historia testamentaria del sujeto implicado en ella, se trata de identificar en los lugares de ese anudamiento la expresión de una crítica «lateral»: oblicua, marginal, fronteriza. Es decir, la práctica de lectura e intervención intelectual de una autoría excéntrica que cristaliza entre los reveses del ensayo académico y las formas profanas de lo menor. Tramada desde esa posición, y amparada en el saber que de esta manera comunica, la honda implicación subjetiva que supone la escritura de Molloy, esa forma de la «verdad» que el afecto inscribe en la letra de quien en ella se arriesga, no deja de inquietar al lector, conmovido y desconcertado ante la intensidad de lo que lee.
Palabras clave: Sylvia Molloy / Desarticulaciones / En breve cárcel / escritura y vida / crítica lateral

\section{Desarticulaciones (2010) / En breve cárcel (1981). In between writing and life: Sylvia Molloy, the contaminated writing of a lateral criticism}

Abstract

In relation to Desarticulaciones (2010) and En breve cárcel (1981) by Sylvia Molloy, this article focuses on the knotting between writing and life that makes the author's writing contaminated, the subjective «truth» that they compromise and the knowledge between semiotic and analytical that incorporate about the link between experience, subjectivity and language. Above the stagnant categories of criticism and fiction, among which life frames a relationship of communicating vessels, and beyond the autobiographical trace that is not synthesized in a testamentary history of the subject involved in it, it is about identifying in the places from this knotting the expression of a «lateral» criticism: oblique, marginal, border. That is to say, the practice of reading and intellectual intervention of an eccentric authorship that crystallizes between the setbacks of the academic essay

Recibido: 11/6/2020. Aceptado: 15/8/2020

Para citar este artículo: Cróquer Pedrón, E. (2020). Desarticulaciones (2010) / En breve cárcel (1981). Entre la escritura y la vida: Sylvia Molloy, las letras contaminadas de una crítica lateral. El taco en la brea, 12 (junio-noviembre). Santa Fe, Argentina: UNL. eoo17 DOI: 10.14409/tb.v1i12.9695 
and the profane forms of the minor. Conceived from that position, and protected by the knowledge that this way communicates, the deep subjective implication that Molloy's writing implies, that form of the «truth» that the affection inscribes in the writing of those who risk it, does not leave to disturb the reader, moved and disconcerted by the intensity of what he reads.

Key words: Sylvia Molloy / Desarticulaciones / En breve cárcel / writing and life / lateral criticism

Desde el principio, en sus poemas, Borges elige la periferia en desmedro del centro y a partir de esa lateralidad, a la vez vital y literaria, escribe su obra. El lugar topográfico borgeano — si nos atrevemos a fijar tal lugar - parecería ser esa línea vaga que deslinda la ciudad y el campo, que permite, por un lado, la nostalgia del centro y, por el otro, esa perspectiva segura — esa libertad— que da el alejamiento (...).

No es inútil recordar que Borges reclama esa marginalidad, justificándola plenamente, para toda la literatura hispanoamericana. Mejor: para toda literatura lateral.

(...)

La irreverencia parece consecuencia inevitable de esa marginalidad aceptada y asumida: declararse marginal —es decir excéntrico — equivale a construir un centro en la misma circunferencia, a reconocer la existencia del centro tradicional y a definirse con respecto a él, pero también a alejarse deliberadamente de ese centro.

Sylvia Molloy, Las letras de Borges y otros ensayos

Todo lo que escribo tiene que ver con un desvío (...). Me interesa lo desviado, lo torcido, lo que no cabe, lo que no está del todo asentado.

Sylvia Molloy, (Entrevista a Sylvia Molloy. En Télam, 15/11/2016)

Para mí la narración y la crítica son dos proyectos paralelos que están en constante diálogo. Casi siempre manejo dos proyectos a la vez, dejando que se enriquezcan mutuamente, que se contaminen.

Sylvia Molloy, (José María Brindisi, Entrevista a Sylvia Molloy. En La Nación, 28/02/2016)

\section{Desarticulaciones (2010): una descolocada «escritura de sí»}

1.

«Tengo que escribir estos textos mientras ella está viva, mientras no haya muerte o clausura, para tratar de entender este estar/no estar de una persona que se desarticula ante mis ojos. Tengo que hacerlo así para seguir adelante, para hacer durar una relación que continúa pese a la ruina, que subsiste aunque apenas queden palabras» (Molloy, 2010:7). Con estas palabras referidas a otras que van quedando apenas sobrevivientes, como vestigios de una relación arruinada por el olvido, Sylvia Molloy (Buenos Aires, 1938) expone el serio propósito sobre el cual se sostiene ese pequeño libro, tan hermoso y preciso como de difícil clasificación, que es Desarticulaciones, publicado en 2010 por la editorial argentina Eterna Cadencia, y un año antes en el volumen crítico-ficcional Excesos del cuerpo. Ficciones de contagio y enfermedad en América Latina (2009), compilado por Javier Guerrero y Nathalie Bouzaglo. Cuarenta y cinco fragmentos 
breves componen Desarticulaciones, este libro apenas precariamente narrativo, más testimonial que ficticio y menos auto-ficcional que íntimo. Un libro en cualquier caso intenso, que reúne la serie de anotaciones intelectuales y afectivas en torno a la experiencia devastadora del Alzheimer, escritas como en los márgenes de otras escrituras, literarias y académicas, anteriores y por venir. Porque, allí donde se anudan la escritura y la vida, Desarticulaciones se refiere al caso de Alzheimer de una mujer - ML., "que todavía está», como reza la dedicatoria— con quien la escritora que atestigua el curso implacable de la enfermedad mantuvo en el pasado una relación amorosa - acaso Sylvia Molloy, lectora experta en los procesos de significación del lenguaje y una de las investigadoras relevantes de esa práctica de lectura y de pensamiento que, desde la crítica literaria, se va definiendo como crítica cultural al interior de cierto latinoamericanismo heterodoxo de las últimas décadas del siglo XX, así como narradora de una serie de textos literarios que se despliegan entre la escritura de sí y su articulación problemática, quien no deja de desaparecer en la memoria de la desmemoriada, al tiempo que (a)firma la honda implicación subjetiva de su trabajo de elaboración significante, esa forma de la «verdad» que el afecto inscribe en la letra de quien en ella se arriesga: ${ }^{2}$

«¿Te conoce todavía?», me preguntan. «¿Cómo sabés que todavía te conoce?». Efectivamente no lo sé, pero habitualmente respondo que sí, que sabe quién soy, para evitar más expresiones de pena. Sospecho que si L. no le dijera mi nombre, antes de pasarle el teléfono cuando la llamo, o antes de abrirme la puerta cuando la voy a visitar, sería una extraña para ella. De hecho, la mención de mi nombre ha perdido su capacidad de convocar, no le provee mucha información. La impulsa, sí, a preguntarme por E. y por «el gato», pero me consta que no sabe quién es E. porque me ha preguntado por ella en su presencia, cómo está tu compañerita. En cuanto a la mención del «gato» así, anónimo, es una expresión más de sus buenos modales. O acaso un lejano recuerdo de un arquetipo platónico, como si me preguntara por la gatidad.

Ayer descubrí que me había vuelto aún menos yo para ella. La llamé y a pesar de que L. le pasó el teléfono diciéndole quién llamaba me habló de tú — de tú y no de vos—durante la conversación. Fue una conversación cordial y eminentemente correcta en un español que jamás hemos hablado. Sentí que había perdido algo más de lo que quedaba de mí. (Molloy, 2010:36³

En este sentido, se trata también de la elaboración significante de un duelo. La elaboración de una primera persona afectada que despliega su escritura a medio camino entre el tejido conjetural propio de la reflexión crítica y la conjetura textual de una suerte de prosa poética que, como en el conocido "Poema conjetural» (1964) de Jorge Luis Borges con el que de alguna manera parece dialogar desde el principio, se va tejiendo en el topos dilatado de una muerte sabida con antelación - la muerte de la otra que ya no habla, tan temida y atestiguada por el yo que se sabe muriendo un poco con lo inexorable de esa muerte- Esta doble conjetura se trama entre una memoria común que se pierde y otra, personal, que intenta ser registrada. Y así, por la vía de una circunstancia distinta a esa en la que se involucran por igual el narrador y el personaje de otro texto del Borges de las imaginaciones insólitas, que tanto ha hecho al interés académico de la autora, «Funes, el memorioso» (1944), la de-subjetivación de la memoria se traduce en la desaparición de un vínculo entre quien ya no se reconoce a sí misma y quien intenta tejer a través de la escritura algún tipo de relato que de algún modo dé cuenta de la experiencia compartida: 
Más de una vez me encuentro diciéndole te acordás de tal y cual cosa, cuando es obvio que la respuesta será negativa, y me impaciento conmigo misma por haberle hecho la pregunta, no tanto por ella, para quien el no acordarse no significa nada, sino por mí, que sigo lanzando estos pedidos de confirmación como si echara agua al viento. ¿Por qué no le digo «sabés que una vez» y le cuento el recuerdo como si fuera un relato nuevo, como si fuera relato de otro que no pide identificación ni reconocimiento? Lo he hecho alguna vez, le cuento cómo una vez fuimos a Buenos Aires juntas y nos paramos en la aduana porque ella llevaba una bolsita con un polvo blanco y los vistas no le creyeron cuando les dijo que era jabón en polvo, usted cree que aquí no hay jabón de lavar, señora, y nos tuvieron horas esperando mientras analizaban el polvo. Ella se divierte, piensa que exagero, yo hice eso, me dice, con retrospectiva admiración. Sí, le aseguro, y otra vez viajaste gratis llevando una estola de visón que mandaba un peletero a una clienta argentina. Y esa vez no te pararon no sé cómo, era pleno verano y vos entraste con la piel puesta. Sigue sonriendo entre satisfecha y desconcertada.

No puedo acostumbrarme a no decir «te acordás» porque intento mantener, en esos pedacitos de pasado compartido, los lazos cómplices que me unen a ella. Y porque para mantener una conversación - para mantener una relación— es necesario hacer memoria juntas o jugar a hacerla, aun cuando ella —es decir, su memoria — ya ha dejado sola a la mía. (32-33)

Por otra parte, como si se tratara de un extraño diario que no necesita del apunte cronológico para ordenarse en el tiempo de la experiencia, y/o de una carta sin remitente a quien dirigir el cara a cara diferido que supondría su enunciación, la escritura que Molloy entrega al lector en Desarticulaciones se formula desde la insistencia de quien no cesa en su intento de tratar de comprender un Real del cual ni la ciencia médica ni el saber psiquiátrico pueden dar cuenta: el vaciamiento de la lengua, allí donde ni la razón ni el deseo la habitan ya. En esto se concentra la observación diaria, así como en la reflexión — por momentos indiscutiblemente barthesianaque despunta de ella ante el desconcierto de la conciencia que la (a)nota:

A medida que la memoria se esfuma me doy cuenta de que recurre a una cortesía cada vez más exquisita, como si la delicadeza de los modales supliera la falta de razón. Es curioso pensar que frases tan bien articuladas — porque no ha olvidado la estructura de la lengua: hasta se diría que la tiene más presente que nunca ahora que anochece en su mente— no perdurarán en ninguna memoria. (13)

Opera impecablemente por deducción, con lo cual compruebo, una vez más, que para pensar razonablemente no es necesaria la razón. (15)

Como la retórica, la facultad de traducir no se pierde, por lo menos hasta el final. Lo comprobé una vez más hoy, al hablar con L. Le pregunté si el médico estaba al tanto de que ML. había sufrido un mareo y me dijo que sí. Por curiosidad le pregunté cómo le había transmitido la información, ya que L. no habla inglés. Me lo tradujo ML., me dijo. Es decir, ML. es incapaz de decir que ella misma ha sufrido un mareo, o sea, es incapaz de recordar que sufrió un mareo, pero es capaz de traducir al inglés el mensaje en que L. dice que ella, ML., ha sufrido un mareo. Es como lograr una momentánea identidad, una momentánea existencia, en ese discurso transmitido eficazmente. Por un instante, en esa traducción, ML. es. (18; énfasis de la autora) 
Vida y escritura parecen anudarse, entonces, en la trama de este texto complejo. Un texto donde se cruzan el problema de la memoria que se va desdibujando y el de la lengua que se vacía, con el de la escritura de quien emprende la amorosa labor de rescatar — y de tratar de significar- algo del orden de lo subjetivo de cuyo desvanecimiento es testigo. Porque la escritura trabaja también en Desarticulaciones muy cerca de otro tipo de saber, más psicoanalítico, si se quiere. Un saber íntimamente incorporado que permite identificar en la escritura la posibilidad de reencuentro con la vida para esa subjetividad que (a)firma el texto de su autoría. Esa «escriba» que emprende el trabajo de registro y elaboración significante gracias al cual el lenguaje arruinado, y la «pétrea insensibilidad» de quien ya no puede decir «yo», consiguen reanudarse como texto:

¿Cómo dice yo el que no recuerda, cuál es el lugar de su enunciación cuando se ha destejido la memoria? Me cuentan que la última vez que la llevaron al hospital le preguntaron cómo se llamaba y dijo «Petra». Una de las personas que estaba con ella vio la respuesta como signo de que todavía era capaz de ironía, se indignó ante las pocas luces del médico que «no entendió nada». Pienso: si es que hay ironía, y no mero deseo de creerla capaz de ironía, se trata de una de esas ironías que llaman tristes. ¿Petra, piedra, insensible, para describir quien se es? (19; énfasis de la autora)

En algunos fragmentos, la observación aguda se impone sobre el dolor de la catástrofe; tal cual leemos, por ejemplo, bajo el título «Cuestionario», donde la impresión de la escritora consigue destacar la potencia semiótica de la imagen literaria producida por la enferma inconsciente de lo que dice:

Recuerdo otro ejemplo de lógica, éste poético. Cuando todavía la llevaba a la clínica donde le hacían evaluaciones para medir la pérdida gradual de la memoria, le pedí un día que me contara qué tipo de preguntas le hacían. Me preguntaron qué tienen en común un pájaro y un árbol. Yo, intrigada: ¿y vos qué contestaste? Que los dos vuelan, me dijo, muy satisfecha. Pensé que sin duda la pregunta había sido otra, pero nunca llegué a saberlo. O quizá no. Acaso algo tengan en común, el árbol y el pájaro. (16-17)

En otros, la ternura que suscitan las extrañas ocurrencias de la desmemoriada desplaza por un momento la cruda conciencia del deterioro, y el absurdo se abre al entre-dos del juego:

Hace tiempo que inventa palabras, como hablándose a sí misma en un lenguaje impenetrable. Ayer cuando la fui a ver repetía jucujucu. Le pregunto qué significa; nada, me dice, es una palabra que inventé. Luego empezó a contar las sílabas con los dedos, rítmicamente, JU-CU-JU-CU. Qué lástima, dice, mirándose el dedo meñique, tiene una sílaba de menos. Por qué no se la agregás, sugiero; puede ser JU-CU-JU-CU-JU. Intenta de nuevo y esta vez hay un dedo para cada sílaba. Qué suerte, dice, y sonríe satisfecha. (40; énfasis y mayúsculas de la autora)

Y en otros, finalmente, la anotación aguda acerca del Alzheimer se deriva hacia lo personal de la lectora de signos, que enhebra al tiempo la propia memoria de una historia de vida donde no dejan de contaminarse mutuamente lo personal y lo intelectual, las escrituras pasadas y las escrituras por venir: 
Durante un tiempo entretuve una teoría que acaso sea acertada. Recordaba que a Borges siempre le había costado hablar en público, al punto que cuando le dieron el premio nacional de literatura tuvo que pedirle a otro que leyera su discurso de agradecimiento. Yo solía identificarme con esa timidez para hablar, yo que casi no podía dar clase y tenía que imaginar que no me miraba nadie para no tartamudear. Hasta que se me ocurrió que Borges sólo había podido superar esa dificultad (la voz que se estrecha no queriendo salir, y que cuando por fin sale, tiembla) al quedarse ciego, porque entonces no veía a su público, que era como pensar que no existía.

Ahora, cuando la visito me ocurre lo contrario. Hablo y hablo (ella no aporta nada a la conversación) y cuento cosas divertidas, e invento, ya lo he dicho, cada vez con más soltura. Y no es que tenga que imaginarme a mí misma ciega sino que es ella la que no ve, no reconoce, no recuerda. Hablar con un desmemoriado es como hablar con un ciego y contarle lo que uno ve: el otro no es testigo y, sobre todo, no puede contradecir. (27-28)

A fin de cuentas, se trata también de la historia de vida de quien termina el relato con un giro inesperado: la abrupta «Interrupción» de quien, a manera de corte, elige separarse de esa «otra» que se ha desprendido ya. El corte es abrupto, en efecto; y su tiempo, breve, tal cual el tiempo de la resolución que le permite a un sujeto, después del largo trayecto que precede al final de un análisis, seguir adelante con su vida, aun a pesar de la culpa que pueda o no suscitar el desprendimiento: «Siento que dejar este relato es dejarla, que al no registrar más mis encuentros le estoy negando algo, una continuidad de la que solo yo, en esas visitas, puedo dar fe. Siento que la estoy abandonando. Pero de algún modo ella misma se está abandonando, así que no me siento culpable. Casi» (76).

2. «[T]ratar de entender este estar/no estar de una persona que se desarticula ante mis ojos» $\mathrm{y}$ «seguir adelante», «hacer durar una relación que continúa pese a la ruina» son los términos a la vez reflexivos y existenciales entre los cuales se dirime la finalidad última de esta escritura. Es decir, su honda razón de ser subjetiva y vital, su profunda implicación y su urgencia. Y, con ella, el ethos que hace a la posición definitiva de lo que bien podría pensarse como una descolocada «escritura de sí» (1986), en los términos discutidos por Michael Foucault respecto de ese tipo de escritura de la antigüedad clásica que, anclada en lo personal, obraba el «decir veraz» sobre la verdad material de la «verdadera vida» del filósofo — sujeto de las ideas y del gobierno de sí.

Estrechamente vinculada con la constitución del sí mismo, y con la responsabilidad que suponía de cara a los otros, según Foucault, esta escritura cumplía una función ethopoiética; toda vez que se comportaba como «un operador de la transformación de la verdad en ethos». Esto es: en una práctica intensa que traducía «la elaboración de discursos recibidos y reconocidos como verdaderos en principios racionales de acción». Bien a través de la anotación cotidiana que atesoraba lecturas de diversa naturaleza, reflexiones no del todo desarrolladas y experiencias propias y ajenas que por alguna razón habían afectado la subjetividad de quien escribía, o bien bajo la forma que asumían esas anotaciones cuando dirigidas al otro de la correspondencia, la «escritura de sí» fijaba un compromiso éticamente asumido entre tales lecturas, reflexiones y experiencias, y el «sí mismo» que las sostenía con su vida. Pero estrechamente vinculada, además, con el registro de una memoria de la propia existencia, se trataba de una escritura a través de 
la cual siempre se volvía sobre lo anotado, que devenía significante en el trazo de la letra que de esta manera lo subjetivaba. Por esta razón, a ella se volvía y ella se compartía, porque servía tanto «a la lectura y a la meditación ulteriores», como a los modos de «sobreponerse» a las oscuras energías del pathos que pudieran comprometer la libertad del sujeto allí donde la catástrofe de lo Real se presentaba ante sus ojos de manera irremediable. Los «hypomnémata», dice Foucault al referirse a los cuadernos de anotaciones, una de las dos formas — la otra es la correspondenciaen que cristaliza una «escritura de sí»,

[c]onstituían una memoria material de las cosas leídas, oídas o pensadas, y ofrecían tales cosas, como un tesoro acumulado, a la lectura y a la meditación ulteriores. Formaban también una materia prima para la redacción de tratados más sistemáticos, en los que se ofrecían los argumentos y medios para luchar contra un defecto concreto (como la cólera, la envidia, la charlatanería, la adulación) o para sobreponerse a determinada circunstancia difícil (un duelo, un exilio, la ruina, la desgracia).

En el caso de Desarticulaciones, como si se tratara de una descolocada «escritura de sí», atravesada en el tiempo y el espacio de su formalización por los trazos de una «historia de vida» - la de esa «otra» que ya no puede «decir yo»—, que tampoco llega a materializarse propiamente como tal, la escritura - esa serie de anotaciones intelectuales y afectivas en las cuales se traman observaciones cotidianas, lecturas de la enfermedad y experiencias compartidas, presentes y pasadas, con el propósito de tratar de comprender algo del orden de lo insoportable, y de conservar lo que va quedando de una relación arruinada por el olvido - abre un espacio donde la vida es litoral del pensamiento, y viceversa. El espacio del cual emerge un texto fragmentario, tan testimonial e íntimo como intenso, donde la una y el otro devienen indisociables, materia y expresión de la proximidad que los reúne. En este sentido, más allá de la primera persona que rige el presente absoluto de la enunciación, y más allá también de cualquier intención autobiográfica (no se trata aquí de eso, ni del «fantasma de la fidelidad que la autobiografía, mal que nos pese, sigue arrastrando»—Molloy 1997:67—), lo que se despliega entre sus líneas es la letra contaminada de esa «liminaridad» constituyente. Y en este sentido, ante todo, lo que en ella se juega como «verdad» es la palabra de quien asume su pensamiento, que es lo mismo que decir su escritura, en carne propia; ese sujeto que da fe con su vida de lo que en su palabra se arriesga. Porque, a fin de cuentas, es un riesgo lo que asume la «escriba» de Desarticulaciones:

\footnotetext{
Al escribirla me tienta la idea de hacerlo como era antes, concretamente cuando la conocí, de recomponerla en su momento de mayor fuerza y no en su derrumbe. Pero no se trata de eso, me digo, no se trata de eso: no escribo para remendar huecos y hacerle creer a alguien (a mí misma) que aquí no ha pasado nada sino para atestiguar incoherencias, hiatos, silencios. Esa es mi continuidad, la del escriba. (Molloy, 2010:38)
}

Este riesgo no dista demasiado del que involucra a la autora en otros textos literarios - En breve cárcel (1981), El común olvido (2002), Varia imaginación (2003), Vivir entre lenguas (2016) y el más reciente Citas de lectura (2017) - en los cuales parece desplegarse una concepción del vínculo entre experiencia, subjetividad y escritura, donde esta última no deja de armarse con dificultad a partir de los retazos de una memoria de la propia vida que, más o menos ficcionalizada y siempre problemática, nunca consigue sintetizarse en la imagen plena de un sujeto convencido 
de la «propiedad» de sus recuerdos, aun cuando ella constituya su única posibilidad de seguir viviendo. Y no dista, asimismo, del que asume en sus más relevantes ensayos de crítica e investigación cultural — Las letras de Borges (1979), Acto de presencia. La literatura autobiográfica en Hispanoamérica (1991-1996) y Poses de fin de siglo. Desbordes del género en la modernidad (2012), entre otros-, donde la tarea de «atestiguar incoherencias, hiatos, silencios» se convierte en señalamiento, llamada de atención sobre objetos y problemas de análisis desconocidos, silenciados o tergiversados por la tradición respecto del canon de la literatura y la cultura hispanoamericanas, que tienden a interrogar los procesos de significación del lenguaje allí donde se involucran con las singularidades subjetivas que a partir de ellos dirimen su lugar en la cultura. Tales textos literarios y ensayos de crítica e investigación literaria y cultural suponen, cada vez, una explícita implicación subjetiva y una urgencia ineludible de escritura que hablan de la posición «a la vez vital y literaria» (Molloy, 2000:58) de la cual parecen desprenderse como expresiones concomitantes de una misma crítica lateral: oblicua, marginal, fronteriza. Es decir, de la práctica de lectura e intervención intelectual de una autoría excéntrica que, entre los reveses del ensayo académico y las formas profanas de lo menor - «escrituras de sí», más o menos ficcionalizadas y siempre problemáticas—, insiste en pensar el anudamiento entre vida y escritura. «Todo lo que escribo tiene que ver con un desvío», afirma la autora en una entrevista publicada en la revista digital Télam, el 15 de noviembre de 2016. A continuación, explica: «Lo que me interesa no es tanto escribir "en contra de" pero sí tratar de ver el revés de las cosas, ver que son mucho menos sólidas o estables de lo que parecen. Y esto se refiere tanto a categorías literarias como no literarias». E insiste, más adelante: «Me interesa lo desviado, lo torcido, lo que no cabe, lo que no está del todo asentado».

El ethos de la escritura que se produce entre tales implicación y urgencia reunidas en una misma posición lateral —la posición de quien parece elegir «la periferia en desmedro del centro» (Molloy, 2000:58), tal cual afirmara la autora en Las letras de Borges acerca del escritor argentino, ese que «me enseñó a escribir (o a leer, que es lo mismo) y me enseñó a pensar: en ese orden» (9)— se materializa, desde el principio de una larga trayectoria en este libro imprescindible sobre la escritura borgeana, a quien Molloy se propone restituir lo marginal y lo excéntrico, lo fragmentario e indeterminado, a contrapelo de las lecturas bajo las cuales ha quedado lapidado el autor «en nombre de la cultura» (58). Y no deja de materializarse, de allí en más, en las letras que la inquietante intensidad de su escritura inscribe, más allá del trazo autobiográfico que nunca termina de cristalizar en una ficción testamentaria del sujeto que escribe, y por encima de las categorías estancas de crítica y ficción, entre las cuales la vida trama una relación de vasos comunicantes.

Entre ambos espacios, en efecto, el problema de la «escritura de sí», como forma fundamental de un trabajo de lenguaje que ancla en lo afectivo de la propia experiencia relatada la posibilidad última de existencia del sujeto (siempre en falta, siempre dividido) que escribe, traza un vínculo tanto estético como conceptual. Un vínculo que, por otra parte, despunta ya desde esa primera novela de la autora, En breve cárcel (1981), y la historia sin destinatario definido que una mujer escribe/inscribe entre sus páginas acerca del reconocimiento de la propia inconsistencia de la pasión, en medio de un desencanto amoroso insoportable y otra relación postergada que asimismo llega a su final, al tiempo que la autora se embarcaba en la elaboración de su libro Acto de presencia. La escritura autobiográfica en Hispanoamérica (1991-1996), acerca de "textos que pretenden realizar lo imposible, esto es, narrar la "historia" de una primera persona que solo existe en 
el presente de su enunciación (...) con el fin de deducir las estrategias textuales, las atribuciones genéricas y, por supuesto, las percepciones del yo que moldean los textos autobiográficos hispanoamericanos» (1996:11).

A diferencia de lo que ocurre en En breve cárcel, sin embargo, y como afirma en algún momento la escritora testimoniante de Desarticulaciones, no hay angustia en esta escritura segunda, que es de igual modo la escritura de un duelo, porque el olvido del «otro» produce formas inéditas para la libre invención de un pasado compartido. Pero entre sus páginas despunta, sí, en todo momento y más allá de cualquier voluntad fabuladora, una "verdad»: la del dolor del testigo que sabe leer lo que a todas luces aparece como una enfermedad de la memoria y de la lengua que ya no dice; una lengua vaciada de subjetividad - la lengua muerta del Alzheimer-. Así como despunta en En breve cárcel, más allá de la (com)pulsión autobiográfica que rige la sintomática escritura de la protagonista e independientemente de que lo autobiográfico haya servido de materia para la fabulación novelesca: la «verdad» de la angustia que abre el camino al conocimiento de sí; y la «verdad» de la falta que emerge al final del texto, como un saber encarnado que al mismo tiempo libera al sujeto de sus más íntimas ataduras pulsionales y lo compromete con la escucha de su deseo. Porque, en definitiva, como expone certera Sonia Mattalía siguiendo de cerca a Lacan:

En el marco de los afectos, la angustia es el único afecto que no engaña, justamente porque explicita en el sujeto su relación con la falta. Afecto cierto, la angustia es una función media entre el goce y el deseo: horror al vacío imposible de colmar, certeza inconsciente de la imposible reconciliación con el objeto, la angustia retorna al sujeto en síntomas diversos que abren la pregunta sobre su deseo. La angustia, con toda su carga de desespero, abre ante el sujeto la posibilidad de interrogarse sobre su deseo y puede ser la puerta de entrada en el conocimiento de sí. (2003:47)

\section{Más allá de lo autobiográfico: En breve cárcel (1981), «escritura de sí» y reanudamiento}

1.

«Comienza a escribir una historia que no la deja: querría olvidarla, querría fijarla. Quiere fijar la historia para vengarse, quiere vengar la historia para conjurarla tal como fue, para evocarla tal como la añora» (Molloy, 1981:13). Henchidas de pathos y situadas en la escena de cierto cuarto anónimo de alquiler - tiempo y espacio de la extranjería, donde se inscribe el acontecer narrativo-, paradójicamente cargado tanto de la memoria de una traición amorosa insoportable, como de la tensión más bien suspendida respecto de una segunda ruptura que sospechamos por venir, estas palabras introducen la primera novela de Sylvia Molloy, En breve cárcel (1981), acerca del íntimo proceso en el que se anudan la escritura y la vida de una mujer sin nombre de cuya «identidad» poco llegamos a saber en realidad. Aunque mucho sepamos, sí, a lo largo del texto, de las pasiones que la movilizan, los fantasmas que la atraviesan, las fantasías que la entretienen, el dolor que la divide y el trabajo de subjetivación de la experiencia en el cual se halla comprometida, más allá de la (com)pulsión autobiográfica —ese impulso entre deseante y gozoso del cual el sujeto es cautivo- que sintomáticamente se piensa a sí misma como deseo de venganza, conjura y evocación de una historia escrita a partir de la «verdad» de la angustia: 
El cuarto donde escribe es pequeño, oscuro. El exagerado cuidado de algunos detalles, la falta de otros, señala que ha sido previsto para otro uso del que pensaba darle; de hecho para el que ocasionalmente le da. Cuarto y amores de paso. No hay bibliotecas — dijo—, no hay mesa para escribir y la luz es mala. Suplió esas deficiencias y ahora libros y lámparas la rodean, apenas eficaces. Sabe con todo que la protegen, como defensas privadas, marcando un espacio que siempre llamó suyo sin hacerse plenamente cargo de él. Como máscaras la ayudan: adentro, para salir de ella misma; afuera, para protegerse de los demás.

Siente la necesidad de empujar, de irritar, para poder ver. Escribe hoy lo que hizo, lo que no hizo, para verificar fragmentos de un todo que se le escapa. Cree recuperarlos, con ellos intenta —o inventa - una constelación suya. Ya sabe que son restos, añicos ante los que se siente sorda, ciega, sin memoria: sin embargo se está diciendo que hubo una visión, una cara que ya no encuentra. Encerrada en ese cuarto todo parece más fácil porque recompone. Querría escribir para saber qué hay más allá de esas cuatro paredes; o para saber qué hay dentro de estas cuatro paredes que elige, como recinto, para escribir. (13)

De difícil lectura, dada la densidad que por momentos adquiere la prosa, el soporte anecdótico del cual depende la estructura de esta novela intensa es, no obstante, sencillo; aunque no por ello condescendiente con el lector en cuya escucha se vierten no solo la violencia pulsional del tormento en el cual se encuentra inmersa su protagonista, sino la crudeza del saber acerca de la propia e irremediable inconsistencia de la pasión que adviene, por fin, a su conciencia. Se trata de una mujer que se sumerge fantasmáticamente en la escritura de un libro que, en principio, pretende «revelar» las vidas de la «otra» a quien se odia por una traición pasada y de la «otra» a quien se ama en el presente, al tiempo en que (re)vive el doble (des)encuentro con quien otrora la lastimara y con esa a quien finalmente ella abandonará. Un libro que termina hablando de la propia vida — de esos «añicos ante los que se siente sorda, ciega, sin memoria»-, de los episodios más o menos traumáticos que desde la infancia la significan y de su propia incapacidad de sostener una relación amorosa. Porque esta mujer escribe, en definitiva, acerca de la imposibilidad del amor, $\mathrm{y}$ «arde en llamas» mientras lo hace, como sugiere la cita freudiana velada en los gritos que la despiertan un día del sueño — «Llaman al padre, hay fuego, un incendio, algo que se quema, papá» (61):

Hace tiempo que vio este cuarto por primera vez; pensó que no volvería a verlo. También prefirió pensar que no volvería a ver a esa mujer que la había esperado: la evitaría si se cruzaran de nuevo. El comentario que le hizo no la sorprendió. En efecto se sentía, como se siente ahora, en discordia con su piel, límite precario que no alcanza a darle forma. Se mira las manos: comprueba la verdad del lugar común al ver dedos despellejados, mordidos hasta la sangre. Mal en su piel, mal con su piel, irritada con esa apariencia llena de fallas, de grietas. De chica la impresionaban mucho más que los esqueletos — que siempre le parecían cómicos - esos cuerpos que ilustran el sistema muscular en los diccionarios. Más de una vez ha soñado con despellejamientos. Por ejemplo, se ha desdoblado, queda como una corteza pero no se ve, ve en cambio a un muchacho enfermo que tiene de la cintura para abajo el cuerpo despellejado, y a ella le ha tocado conservar la piel inútil de él. El muchacho de su sueño no tiene pies, tiene muñones, no puede caminar, se cae y llora roncamente; entonces ella teme que se muera, teme también que le vean las piernas llagadas, se apresura a levantarlo. Pero no logra hacerlo porque cambia la escena. Cuando ve la fusión de los dos, del despellejado y de ella misma que se ha quedado con la piel inútil aparece un escenario: dos figuras bailan, representando los dos papeles y ella, ya espectadora, no se siente afectada. 
La circularidad la impresiona, el hilo, siempre igual, que va dejando atrás. Mal protegida por su piel ineficaz recorre los mismos lugares, repite las mismas conductas. Hoy está en un lugar —en uno de los lugares - donde la lastimaron, en este cuarto conocido del que renegaba en el recuerdo.

En otra ciudad, y un año después del primer encuentro en este cuarto, volvió a ver a la mujer que la esperaba aquí y no pudo evitarla. Con ella volvió a aprender la zozobra, la angustia del que quiere y lo dice, invitando al otro para que destruya. También volvió a aprender los celos, el odio y el deseo, la necesidad — nunca satisfecha— de la venganza. Hoy, en este momento mismo, retiene de aquella mujer dos únicos gestos de ternura. Una mañana, creyéndola dormida, le besa los párpados. Otra vez, en el probador de una tienda y en vísperas de un viaje, la mujer la acaricia y le pide que se vaya rápido. Pero de pronto recuerda un tercer gesto. Un día, un domingo, salieron a almorzar. Había nevado mucho, en el campo hacía frío. Cuando volvían en el automóvil se sintió muy triste. Ella conducía; la mujer - Vera: ¿por qué le cuesta nombrarla? - dejó caer la cabeza sobre su falda. Cree que no hablaron. Se emociona ante el recuerdo de ese tercer gesto, aparecido mientras escribía las dos ternuras que pensaba únicas.

Pero también recuerda una larga noche de humillación cuando se la relegó a otro cuarto y le fue dado oír, con la precisión que acusa la pasión irritada, los más mínimos detalles de un acto de amor. Quiso morir, juró vengarse y sólo atinó, al día siguiente, a rechazar un desayuno que se le ofrecía. Le gustaría pensar que fue un gesto definitivo, que nunca más comió con Vera, pero sabe que no fue así. Volvió a verla y una noche conoció a su nueva amante, de quien más tarde se enamoraría. Era Renata, la persona a quien ha esperado toda esta tarde, la persona que acaba de llamarla para decirle que hoy ya no podrá venir. (15-16)

Tres relatos superpuestos hacen al proyecto del texto ficcionalizado en la novela — tres relatos que se encuentran en un mismo «desgarramiento inquisidor»: la historia de Vera, una antigua amante con quien la protagonista compartiera en otro tiempo el espacio que ahora es el de la escritura; la historia de Renata, la amante que vuelve a verla, y/o que se retrasa, y/o que no llega, en lo que se vislumbra como una inminente separación; y la historia familiar, que apenas consigue articularse en torno al vínculo espectral con el padre, la madre, la tía y la hermana desdibujado por la muerte trágica y/o por la distancia insalvable del malentendido:

Una clave, un orden para este relato. Sólo atina a ver capas, estratos, como en los segmentos de la corteza terrestre que proponen los manuales ilustrados. No: como las diversas capas de piel que cubren músculos y huesos, imbricadas, en desapacible contacto. Estremecimiento, erizamiento de la superficie: ¿quién no ha observado, de chico, la superficie interior de una costra arrancada y la correspondiente llaga rosada, sin temblar? En ese desgarramiento inquisidor se encuentran clave y orden de esta historia. Por un lado, intenta demostrar un itinerario que se inició aquí doblemente: cuando vio por primera vez a Vera, hace cinco años; cuando regresó hace poco a ese cuarto sin quererlo y empezó a rehacer su vida, con la urgencia del recuerdo. Por otro lado, intenta armar otro itinerario alrededor de Renata, la mujer que no ha venido, la mujer que logró desprender de Vera. Por fin - y de manera oscura — tiñe esos dos lados con una infancia que evitaba, de la que creía que no hablaría y de la que evidentemente quiere hablar. Poco queda para mí, se dice, ante el abarrotamiento de este camino trazado. No ve claramente el nexo entre Vera, Renata y su infancia, no cree, en el fondo, que ese nexo exista. Sólo sabe que por el momento — poco queda para mí— habrá de anotar esas tres líneas que quizás más adelante se combinen, que quizás más adelante revelen, como las capas de piel en el libro de anatomía, el sistema de su imbricación. (23-24) 
Por otra parte, como si se enfrentara a ese trayecto complejo y solitario que supone la travesía de un fantasma en la experiencia psicoanalítica, el personaje central de la novela no dispone para su escritura de otro soporte que no sea el del recuerdo, siempre esquivo y confuso, distorsionado por el afecto. Ni de más compañía que la que precariamente le ofrecen las visitas esperadas e inesperadas de Vera y de Renata. Ni de algún asidero distinto al que le provee la serie de «anotaciones» de sueños, fantasías e imágenes aisladas y fragmentarias de su propio deseo cautivo a las cuales recurre cuando la escritura se topa con el silencio. Ni de otra destinación que la de culminar el libro que al final se conserva como un documento del propio trabajo subjetivo cursado en y por la escritura. Está sola y escribe en estado de angustia, aun cuando tanto la escritura como los acontecimientos que se van produciendo al tiempo no dejan de suscitar la permanente revisión crítica — esa forma de la distancia, mediadora del sentido - que en todo momento interviene en el relato a manera de puntuación. Sabe, sin embargo, como afirma el narrador omnisciente que actúa como intermediario entre su conciencia y el lector que con ella se arriesga en la lectura de un texto tan espeso como asfixiante, «que no escribe para conocerse, que no escribe para permanecer, que no escribe para hacerse daño» (24). Y sabe, además, más allá del «exorcismo que se propone» (24), «que le duele mucho contar esta historia» (25):

Mira una vez más el cuarto en que vive, piensa que está bien mientras logre seguir escribiendo. De ninguna manera ha tenido aquí la sensación de estar en un ataúd, experimentada tantas veces en otros cuartos, al despertarse en medio de la noche. De ninguna manera. (Pero piensa, sí, que ha tenido ganas de fugarse, de abandonarse, cuando no escribe. Este cuarto tiene una ventana desproporcionadamente grande, también un sólido balcón de hierro al que a menudo añade una soga — tanto para el balcón, tanto para mi cuello — cuando se siente desamparada.)

La historia que pretende narrar se ha alterado. La alteraron el llamado de la mujer que hoy ya no vendrá y los menudos hechos que pueblan el intervalo, que separan ese llamado de esta frase. Escribía con furia y con curiosidad; ahora escribe porque no sabe qué hacer, se exaspera porque no sabe adónde irá a parar este relato, de pronto informe. Había pensado escribir una historia de celos en el espacio marcado por una espera, con plena conciencia del truco que empleaba, con conciencia —además— de los límites que preveía para esa espera. También tenía conciencia del truco en aquellas fantasías de la cama, del baño; se pregunta si la imaginación voluntariosa, nada mágica, que intervenía en esas invenciones no era parte principal del placer que le procuraban. Lo malo es que ahora la han tomado desprevenida; no pensaba que tendría que volver a inventar.

La mujer a quien esperaba no viene. Querría describirla, evocar el primer encuentro hace cuatro años en casa de Vera, en pleno centro de aquella ciudad sofocada por la nieve. Ciudad que no nombra por ahora, que acaso no nombre en cada nueva copia de este texto; propone geografías vagas, una latitud frígida aceptable, un invento nevado que no la convence, que tacha. Querría no nombrar, por coquetería, con desenfado. Sabe que nombrar es un rito, ni más ni menos importante que la inscripción de una frase trivial. Pero también sabe que los nombres, las iniciales que había escrito en una primera versión, han sido sustituidos; la máscara del nombre que recuerda, del nombre con que dijo, con que creyó que decía, ha sido reemplazada por otra, más satisfactoria porque más lejana. Se pregunta por qué disimula nombres literalmente insignificantes cuando pretende transcribir, con saña, una realidad vivida. (18-19) 
Así, pues, en la doble soledad que los epígrafes de la novela anuncian como prisión y como refugio a la vez, según subraya Francine Masiello en un artículo agudo de 1985, en torno a la "producción del sujeto» en este texto, que concibe como consolidación de una posición feminista contraria a las lógicas patriarcales de definición de lo femenino que rigen otras ficciones latinoamericanas de la época, en En breve cárcel la escritura, esa insistente inscripción de una letra que apenas vamos reconstruyendo entre la reticencia, la elipsis y el desvío —-maneras todas de trabajar con los «restos»—, transcurre junto a los encuentros y desencuentros de vida que se van sucediendo simultáneamente. Y en ese transcurrir difícil, la mujer que escribe se desplaza de la terrible posición de quien imagina sutiles violencias para sobrevivir al odio — como esas que imaginara el Borges de las pasiones terribles: las del narrador de «El Aleph» (1949), por ejemplo, contra la en otro tiempo amada Beatriz Viterbo- , a la que permite la intervención autoconsciente de quien parece jugarse el ser en el tránsito inestable del odio al amor y del amor al conocimiento - como esa que Sor Juana Inés de la Cruz encarnara entre las cuatro paredes de la celda donde plegaba y desplegaba los saberes/los versos de su «Primero sueño» (1692), el largo poema medular del barroco americano, que Sonia Mattalía lee como un tratado de las pasiones (2003:101 y ss.)—. Porque, como afirma Mattalía, de la mano de Lacan, existen tres pasiones fundamentales del ser, que son las pasiones por las que transitan tanto el sujeto lírico desplegado por la monja mexicana como la protagonista de En breve cárcel: el odio, el amor y la ignorancia, anudadas de manera distinta entre lo Real, lo Simbólico y lo Imaginario que constituyen los sistemas de referencia del sujeto; es decir, de esa singularidad humana que se cifra, cada vez, entre la experiencia de sí y el lenguaje que la escribe como/con anterioridad:

En su entrechocar, por lo que cubren y descubren, se esclarece una ética que, asiendo a los afectos en su evidencia engañosa, los interroga y los hace entrar en el decir, un decir que cada sujeto produce al dejar fluir un saber del inconsciente del cual esas pasiones dependen. Es ese saber no formalizado, forcluido en la represión, el que nos hace padecer.

Los sistemas de referencia — lo real, lo simbólico y lo imaginario— se sitúan en la dimensión del ser y las pasiones son sus vías de realización: «Sólo en la dimensión del ser, y no en la de lo real, pueden inscribirse las tres pasiones fundamentales: en la unión entre lo simbólico y lo imaginario, esa ruptura, esa arista que se llama el amor; en la unión entre lo imaginario y lo real, el odio; en la unión entre lo real y lo simbólico, la ignorancia» (Lacan 1981a:392). Cada una de ellas se delinean en una encrucijada; se anudan en una doble valencia que permea una cualificación singular, una coloración que las matiza en cada sujeto. (2003:51-52)

Por ello, independientemente de que no haya sido «conocerse» el propósito de la escritura, otro tipo de saber le aguarda al personaje en el trayecto de un trabajo sobre el significante cuya razón de ser se va modificando a medida en que se va sucediendo el tiempo de lo que en ella se elabora con la intensidad de un dolor demasiado profundo. O sea: el saber de la propia impotencia frente a un Real que allí se manifiesta tan insoportable para el sujeto como ineludible: «no (se) puede unir lo despedazado» (127), ni en la vida ni en la escritura; así como no se puede, tampoco, fijar en la escritura la imagen plena de un pasado que apenas se presenta de nuevo a la conciencia mediante los retazos aislados e imprecisos de lo que alguna vez fue la imprecisa percepción de la propia vida. Aun cuando se puede, sí, asumir esa imposibilidad; y, a partir de ella, volver a 
afrontar el curso de la propia existencia. Ambos saberes entre semióticos y analíticos, literarios y culturales en los que se asienta la lectura del vínculo entre experiencia, subjetividad y lenguaje que lateralmente se piensa en esta novela, adquiridos en la escena de una íntima escritura una escritura en la cual algo del orden de lo subjetivo se arriesga-, traducen también un cambio de posición en el personaje protagonista: del desasosiego de la primera parte del texto a la cosa lapidaria y pausada del final, esa suerte de doble desprendimiento — de la propia (com)pulsión autobiográfica, y de la fantasía de venganza, conjuro y evocación que la animara-, que no solo cierra el proceso de la escritura, sino también el doble vínculo con Vera y con Renata que hiciera al pathos inicial de su programa:

Quién se va, quién se fue, quién no se puede ir: quién, por fin, rompe. Lentamente se ha decidido a levantar este cuarto vuelto inservible, recoge y desecha lo que ha acumulado en él. Desgarra papeles anotados, cartas: lo escrito viaja tan mal. Hoy, además, lavó los vidrios de las ventanas, quiere entregar la casa limpia aunque sabe que en ella quedan rastros suyos (...).

Deja de escribir, mientras sigue atronando la música y mientras Renata duerme, se acerca a la ventana. Al mirar el patio vacío - a esta hora sin chicos ni porteros - se pregunta hasta qué punto contribuye a esta declaración de amor, que sabe cierta, el hecho de que Renata la ha reemplazado por otra persona. El amor propio, se dice como para cauterizar una herida, suele llevar a la exageración. De pie ante la ventana, se acusa de mezquindad, se harta de su manía de análisis. Diseca, sí, con la mirada fija en un cuarto de enfrente iluminado, donde come pacíficamente y con la indiferencia que produce el acostumbramiento, una pareja. Comen como comían sus padres, cuando a ella la habían mandado a la cama y los espiaba desde lo alto de la escalera. Era un rito, hablaban apenas, conocían de antemano las preguntas y las respuestas. Diseca, sí, ante la pantalla que se le presenta desde esta ventana y mientras Renata duerme, adivina los mínimos reproches, las discusiones superficiales, la pequeña complicidad que ella nunca ha conocido porque nunca ha vivido con nadie. Diseca — sobre todo — porque se aplica a algo muerto, el contacto con Renata que ya añora, que ya le duele en todo el cuerpo, porque sabe que no volverá a tocarla. Sigue mirando por la ventana, sigue escuchando la música, diciéndose que Renata no está allí detrás de ella, y que pronto se tendrá que ir. Termina de hacer las valijas, las cierra, despierta a Renata que se despereza como la primera vez que la despertó con los ojos entrecerrados.

Ya no la besa, ya no hay tiempo. Se va de esta ciudad a otra, y acaso a otra después. Prometen volver a verse, tienen que volver a verse, se dicen mientras Renata la lleva al aeropuerto, mientras ella sabe que Renata —la única mujer a quien ha querido— - volverá al lugar que se ha preparado con otra. No se verán más.

Se instala en el bar del aeropuerto a esperar. Bebería hasta insensibilizarse pero no lo hace. Ha decidido armarse para el ejercicio: no hay alcohol, ni droga, ni tabaco que la ayuden. Se dice que no escribirá de nuevo hasta que vuelva a ver a Renata — o a Vera, o a Clara, o a su madre — pero sabe que es mentira: no volverá a ver a ninguna. Desamparada, se aferra a las páginas que ha escrito para no perderlas, para poder releerse y vivir en la espera de una mujer que quería y que un día, faltó a una cita. Está sola: tiene mucho miedo. (156-158)

En este sentido, del encierro en el cuarto de alquiler al viaje que ese otro espacio del anonimato - el aeropuerto - promete, entre el inicio y el final de esta novela, vida y escritura se anudan en torno a una suerte de tensionamiento del sujeto entre, por una parte, las pasiones que 
lo movilizan, los fantasmas que lo atraviesan, las fantasías que lo entretienen, el dolor que lo divide; y, por otra, el trabajo de subjetivación de la experiencia que, a través de la escritura, le permite su final reanudamiento. Esto es: su asumirse como una instancia de vida responsablemente posicionada en relación con sus elecciones de deseo — abandonar París, esa ciudad que casi al final de la novela adquiere por fin un nombre; abandonar el pasado con Vera y abandonar también a Renata, aun cuando sea ella la mujer a la cual se ama-. Porque dejar atrás lo arruinado por los excesos de la pasión supone asimismo una apertura a la propia existencia heterónoma de quien apenas lleva consigo ese «registro», el documento de su propio extravío. Es decir, la escritura: ese resto desprendido del propio cuerpo — del insomnio, el consumo, el agotamiento extremo, el padecimiento físico y subjetivo - que, una vez escrito, puede ser también, en adelante, leído. Estrechamente anudada con la vida, entonces, la escritura es aquí concebida como grafo y como gasto; pero es, asimismo, la posibilidad de un "pase» del encierro que se deja atrás al viaje por venir. De allí que su final sea, también, como el final de un análisis —ni heroico, ni superyoico: un final que anuncia el desplazamiento del pathos al ethos; o, lo que es igual, del odio y el amor vividos en la ciega ignorancia de lo que se sufre en carne propia al conocimiento de sí que su elaboración significante hace, si no distinto, cuando menos soportable:

Pero no es sólo el reconocimiento de ese saber inconsciente, actualizado y elaborado en la palabra, lo que el proceso analítico produce; sino que el poner nombre a lo innombrado hace soportable la sabiduría.

Cabe señalar que esta travesía de modular el goce y atravesar el fantasma del sujeto no pretende la instauración de un sujeto unido sin fracturas en la relación con su deseo, tampoco aspira a restaurar una totalidad perdida quién sabe dónde, sino que produce un saber: el Otro no existe, en su lugar no hay nada. En esa búsqueda y en ese encuentro el sujeto puede hallar la autorización a sí mismo para no ceder en su deseo. Emerge, así, una ética de la acción sustentada en el reconocimiento del deseo; una ética paradojal que pivota entre la modulación del goce y la realización del deseo. (Mattalía, 2003:64)

2.

Tres décadas antes de Desarticulaciones, y asimismo organizada en torno a la escritura de la propia experiencia y al trabajo subjetivo en ella comprometido, aunque más bien concebida de cara al olvido posible que a la imposible conservación de la memoria, En breve cárcel se publicó por primera vez en 1981. Tuvo en ese momento poca circulación en Argentina, quizá por el hecho de que se trataba abiertamente de la representación de un triángulo amoroso lésbico, como ha inferido alguna vez la crítica, o por la densidad del pensamiento que allí se fundía con la trama novelesca de lo que podría pensarse como una «ficción teórica», cercana a la que ensayaban también hacia las últimas décadas del siglo XX otros autores latinoamericanos vinculados al ámbito académico — Ricardo Piglia, por ejemplo, con textos como Respiración artificial (1980) y La ciudad ausente (1992). No obstante ello, y posiblemente por las mismas razones, desde el principio capturó la atención de lectores expertos bien ocupados en el campo de los estudios feministas, bien orientados a explorar las representaciones homoeróticas de la literatura y el arte en América Latina. Se volvió a editar diez años después, en 1998; y, más recientemente, en 2012, en la colección dirigida por Ricardo Piglia para el Fondo de Cultura Económica, «Recienvenido», tendente a visibilizar obras que en su tiempo no tuvieron una gran difusión y que demuestran hoy su indiscutible importancia en el mapa de la literatura latinoamericana contemporánea. 
De él destaca Piglia el «efecto de intimidad» y el «efecto de verdad», que hacen que la novela sea leída «como si fuera una autobiografía»:

La novela de Sylvia Molloy, sabiamente narrada en presente y en tercera persona, produce un efecto de intimidad que es único y es inolvidable. La historia se construye desde tan cerca que nos da la sensación de estar espiando una escena prohibida, y el efecto de verdad — la certeza de que la historia es cierta y ha sucedido tal cual se cuenta - es tan nítido que leemos En breve cárcel como si fuera una autobiografía.

La novela se instala en el presente porque el presente es el tiempo de la pasión y trata de no salir del cuarto donde se espera — o se desea — que vuelva a suceder lo que ya ha sucedido.

Conozco pocas novelas que hayan narrado con tanta intensidad y belleza la historia de una pasión. (5)

Porque es la intimidad de las pasiones el tema fundamental de este relato; así como es la interioridad sobreexpuesta del personaje que pulsa entre sus páginas lo que este vuelca sobre el lector, inquietado entonces por la cercanía con que se le revelan los sobresaltos de su alma y los estremecimientos de su cuerpo... Sin embargo, y a pesar de que pueda ser leída «como una autobiografía» (a fin de cuentas la autobiografía es también «una manera de leer» —Molloy, 1996:12—), En breve cárcel no lo es en realidad, ni pretende serlo; toda vez que no es la prosopopeya la figura que la rige, ni la representación de una historia testamentaria de la propia vida, lo que finalmente se produce entre sus páginas. ${ }^{4} \mathrm{O}$ lo es, si se quiere, en la medida en que traduce respecto de la autora «lo sustancial de su pensar», como diría el Borges de las anotaciones incisivas («El tamaño de mi esperanza», 1926), citado por Molloy en un breve ensayo donde se propone «entretejer vida y letra de Borges, o más precisamente personalidad, autobiografía y cita en Borges» (2000b:227). Es decir, oblicuamente, como toda escritura. Según expresa Molloy, en una entrevista realizada por Graciela Speranza:

Me interesan las tácticas de la autobiografía, por eso he escrito críticamente sobre el género, pero me distancio de ellas en la práctica de la ficción. Creo que el autobiógrafo rescata reliquias y con ellas compone un mosaico que aspira a la fijeza, en algunos casos, a la monumentalidad. Es la propia figura que se quiere legar al lector. Yo prefiero detenerme antes: no componer la figura con la memoria sino descomponerla, refraccionarla, desfigurarla, digamos. Por eso elegí la tercera persona en En breve cárcel, para distanciarme de un yo abrumador que quitaría movimiento. Mi novela juega con el género, recurre mucho a la anécdota biográfica, imposta la enunciación en primera persona, cuando dice, literalmente, en dos o tres lugares del texto: «yo». Además, como en el pasaje que usted cita, En breve cárcel reflexiona sobre la autobiografía, se refiere sin nombrarlos a modelos del género (Sor Juana y Sarmiento). Es sin duda, una autobiografía oblicua; pero toda escritura es una autobiografía oblicua, ¿no? (Molloy en Speranza:141)

En este orden de ideas, y más allá de la materia autobiográfica que haya podido alimentar la ficción novelesca, el interés manifiesto de la protagonista por la autobiografía, que por otra parte duplica la cosa compulsiva — sintomática, henchida de pathos— de su propósito inicial de vengar, conjurar y convocar a través de ella la herida causada por la traición amorosa, trama una estrecha relación entre la novela y la reflexión académica que Molloy despliega a propósito de este asunto en Acto de presencia. La escritura autobiográfica en Hispanoamérica (1991-1996), libro escrito al tiempo en que se escribía En breve cárcel y a raíz de una misma inquietud acerca de 
la escritura confesional, tal como expone la autora en una entrevista realizada por José María Brindisi y publicada en La Nación el 28 de febrero de 2016: «Cuando escribía En breve cárcel estaba pensando las diversas formas y objetivos de la escritura confesional y de ahí salió no solo la novela sino también el impulso para mi libro sobre la autobiografía». ${ }^{5}$ Una relación, pues, de vasos comunicantes, que tiende a reunir tanto su escritura de ficción como sus lecturas críticas en torno a la literatura y la cultura hispanoamericanas; y una relación autoconsciente, además, como se pone de manifiesto en esa suerte de poética crítico-literaria que es su ensayo «Ficciones de la autobiografía» (1997):

Quiero hablar de un tema, mejor de una intersección, que alimenta toda mi escritura, tanto crítica como de creación, esto es, la intersección entre ficción y autobiografía. No elijo este cruce al azar. Como crítica, vengo dedicándome desde hace tiempo a la escritura autobiográfica y al uso estratégico de lo que se suele llamar (sin siempre tener conciencia de qué, precisamente, se entiende por el término) «lo personal». Como escritora de ficción, suelo adaptar lo autobiográfico para fines narrativos. Finalmente, mi novela En breve cárcel se ha leído, con frecuencia, como autobiografía, al punto que más de una vez la he oído describir como narrativa en primera persona o como ficción autobiográfica, dos cosas que, estrictamente hablando, no es (...).

Cuando empecé a escribir En breve cárcel nunca pensé que mi novela fuese, acaso, «autobiográfica». Sí en cambio le adjudiqué a la protagonista la pasión por autobiografías ajenas. El acontecimiento inicial de mi novela es, por cierto, algo que me ocurrió. Estaba en París, buscando apartamento, y en estado de autoconmiseración agudo. Acababa de terminar una relación y, a pesar de haber sido yo la iniciadora de tal ruptura, sentía, como suele suceder en esos casos, que yo era la abandonada. Sólo retrospectivamente me di cuenta de que, en ese momento de víspera de escritura, dos otros acontecimientos recientes pesaban en mi vida. Una mujer que había sido muy importante en mi vida acababa de suicidarse; otra amiga, luego de varios y penosos trastornos, algunos de los cuales había presenciado yo misma, había sido internada. Y sin embargo ninguno de esos dos episodios, que sin duda dejaron su marca traumática en mí, fueron recuperados en la novela. En el momento de la escritura, mi supuesto «abandono» y la increíble coincidencia que hizo que, al responder a un aviso de periódico como el personaje de Aura, me encontrara inesperadamente en un apartamento en el que ya había estado y donde se había dado un encuentro que me había marcado mucho, superó narrativamente los otros dos acontecimientos. Este gesto de selección, que se da al inicio de la ficción y asegura su impulso, se da también, sugiero, en toda autobiografía. (65-67; énfasis de la autora)

Más que interrogar los detalles de esa «intersección» entre la ficción y la autobiografía, me interesa destacar que allí donde ella se produce se despliega, también, una lectura del vínculo entre experiencia, subjetividad y lenguaje. Esa «liminaridad» —la vida como siendo litoral de la letra que la inscribe, y viceversa - que no solo se incorpora como saber en En breve cárcel, sino que atraviesa los textos heterogéneos que hacen al interés vital y literario de la autora, más allá de la distancia que tiende a separar la crítica de la ficción. Ello no significa que tal vínculo se cifre en la consolidación de un espacio apacible de encuentro entre el sujeto que escribe y la experiencia de vida que su escritura traduce. No obstante, representa la posibilidad de lidiar con la violencia que el recuerdo acarrea; $y$, en consecuencia, de confrontarse con eso que de la experiencia vivida resulta irremediable. «¿Cómo sacar fuera una violencia, cómo escribirla?» (Molloy, 1981:112), se 
pregunta la protagonista de En breve cárcel, en medio del proceso de análisis que acompaña la letra que se inscribe en el papel, como se ha inscrito ya en el cuerpo de quien no puede otra cosa que seguir escribiendo. Y, por otra parte, «¿Cómo acatar las prohibiciones del recuerdo cuando está ante sus manos y dentro de un cuerpo que le devuelve, como un manuscrito desmañanado, corregido y lleno de tachaduras lo que en él ha inscrito? Podrá modificarlo, decirse que lo modifica, pero bajo lo que añada y lo que tache persistirá la letra primera que no consigue anular» (111). Esa letra escrita que presiona, como señala la autora a propósito de Borges, «que inscribe una tensión» (Molloy 2000:57), y que lo hace una y otra vez.

La subjetividad que se hace cargo de esta inscripción —acaso Sylvia Molloy, narradora (y) crítica, quien no deja de (des)aparecer en el gesto de su escritura (Agamben:77 y ss.) — encarna en un cuerpo/corpus atravesado por la marginalidad voluntariamente asumida y por la necesidad de aferrarse a la escritura que emerge de ella como única respuesta posible ante la catástrofe de lo Real, tal cual se desprende de otra serie de textos fragmentarios, Varia imaginación (2003), otra descolocada «escritura de sí» en la que se diseminan los trazos de una «historia de vida» que tampoco consigue articularse en una ficción testamentaria de la propia existencia de quien en ella (y con ella) se arriesga:

En septiembre de 2001 cambió el tiempo, mi tiempo, quiero decir. No me refiero a que los acontecimientos del 11 me hayan hecho sentir frágil, con un futuro incierto, aunque todo eso se dio. Me refiero a la temperatura, a las estaciones, como si el ataque hubiera desordenado algo en mí de manera mucho más profunda. El día del atentado hacía un tiempo magnífico en Nueva York, de primavera más que de otoño, con un cielo muy claro y un sol radiante. Así como quedaron fijas las agujas de muchos relojes cercanos a la catástrofe, quedó suspendido el clima, en un buen tiempo inamovible, durante semanas, meses. Se esperaba el invierno pero el invierno no vino. Las plantas empezaron a brotar como si comenzara la primavera, el cielo siguió azul, apenas llovió. Fue entonces cuando empecé a soñar con Buenos Aires, noche tras noche. Fue entonces cuando me sorprendí pensando en mi madre, mi padre, mi tía, mi hermana: todos muertos. Eran recuerdos o sueños (no estoy segura de poder distinguir entre los dos) de un pasado muy lejano, cuando todavía no sabía que no iba a pasar el resto de mi vida en Buenos Aires, recuerdos de niñez, de adolescencia. Sueños (o recuerdos) de tonos de voz, de expresiones enterradas en mi memoria, de imágenes sueltas, desconectadas, en general felices, a pesar del ruido de helicópteros que también contribuía a que se me mezclaran las dos ciudades. Creo que el tiempo, ese radiante otoño suspendido, tuvo mucho que ver con mi desorientación, el tiempo que se me antojaba el de Buenos Aires: como hacía calor en octubre haría todavía más calor en noviembre, terminarían las clases, y para Navidad habría olor a fresias y a jazmines.

Ese desfasaje me persigue, impide que me instale del todo en la cronología corriente, mucho menos en esas estaciones invertidas cuyas temperaturas, cuando hace años cambié de hemisferio, me costaron un largo aprendizaje. Ahora es abril pero a veces creo que estamos en septiembre. Sé que estamos por entrar en verano pero hay días en que algo me dice que está por llegar el invierno, con sus lluvias y su humedad, casi lo presiento en el viento fresco que a veces sopla por la tarde. Y también lo presiento en el ladrido desolado de un perro que me llega desde el fondo de manzana, que es el de aquel perro de la casa del fondo, en Olivos, que ladraba de tarde cuando tenía frío. Estoy en Buenos Aires, me digo, estoy en casa de mis padres. No no me he ido. Está refrescando, mejor que entre. (Molloy, 2003:103-105) 


\section{Notas}

$1 \mathrm{El}$ presente trabajo forma parte de una investigación más amplia en torno a algunos «casos» de autorías excéntricas de la crítica cultural en América Latina, las «formas profanas» en que se manifiestan y las correspondencias que se traman entre la concomitante singularidad de sus prácticas desplazadas. Identifico en ellos una transposición del intelectual que, a contrapelo de cierto latinoamericanismo atravesado por las crisis y contradicciones de su difícil adecuación a los cambios implicados en el tránsito de las últimas décadas del siglo XX hacia las primeras del XXI, despliega sus lecturas inquietas e inquietantes acerca de la cultura latinoamericana y de sus vínculos estrechos con lo social desde una suerte de posición diaspórica. Es decir, una posición que se realiza al sesgo tanto de los términos que organizan los saberes propiamente académicos de las Ciencias Sociales y las Humanidades, como de los semblantes más o menos orgánicos y/o abiertamente mediáticos que se supone debe asumir para participar en el debate público sobre los problemas que le atañen. Silviano Santiago, Sylvia Molloy, Josefina Ludmer, Ricardo Piglia, Diamela Eltit, Raúl Antelo y Julio Ramos, entre otros que podría haber identificado, son los autores a los que me aproximo en mi pesquisa; y son las maneras en que en ellos se describe la excentricidad de una autoría descolocada, el objeto que hace al interés de mi acercamiento cada vez.

2 En su libro Rituales de la verdad. Mujeres y discursos en América Latina, Nuria Girona Fibla interroga la relación entre escritura y subjetividad en un corpus heterogéneo de mujeres latinoamericanas, así como el «efecto de verdad» de algunos discursos escritos por mujeres y los «rituales» que apuntalan sus maneras de producirse como tal. De la mano de Foucault, la autora advierte: «Cada sociedad tiene su régimen de verdad, su "política general de la verdad" y delimita "los mecanismos y las instancias que permiten distinguir los enunciados verdaderos o falsos, la manera de sancionar unos y otros; las técnicas y los procedimientos que son valorizados para la obtención de la verdad; el estatuto de aquellos encargados de decir qué es lo que funciona como verdadero" (Foucault, 1979:187)./ La cuestión es precisamente que los hechos nunca "hablan por sí mismos" (...), sino que una red de dispositivos discursivos los hace hablar; lo cual no equivale estrictamente a proclamar el relativismo de la verdad o su imposible totalización: no hay verdad, pero sí se produce verdad» (20; énfasis de la autora).
Y más adelante, con Lacan, puntualiza: «En este punto ciego de la teoría foucaultiana podríamos tomar la advertencia de que "la verdad tiene estructura de ficción" (Lacan, 1991:8), para señalar de lleno su lugar vacío, al modo de un relato, no en el sentido de quimera fabulosa, sino entendida como un aparato linguiístico, un montaje de motivos y deseos que resguarda otros enunciados, intereses y valores. Este lugar vacío la instala bajo la sospecha de la apariencia en la que se acomoda y de la ausencia inherente al lenguaje que la contiene - la ficción del lenguaje, que la redunda - Una tramoya, la ficción - - y los huecos que resguarda - se alza como la médula y el tejido de la estructura de la verdad» (20). Un paso más al respecto, en otro libro que también se concentra en la relación entre escritura y subjetividad, así como en el «efecto de verdad» que rige el «espacio biográfico» en el cual la escritura de la propia vida consigue pensarse más allá de la heterogeneidad de las formas en que se materializa, El espacio biográfico. Dilemas de la subjetividad contemporánea, Leonor Arfuch destaca el valor testimonial de estas narrativas de la vivencia que postulan la verificación de lo enunciado por el yo en la presencia «real» de la "persona» que lo afirma; un valor que, central en la consolidación del sujeto moderno en Occidente, se expande exponencialmente en la contemporaneidad. Entre ambos planteamientos parecería ponerse en evidencia que allí donde se articulan experiencia, subjetividad y escritura se establece el espacio de una «verdad» que ya no refiere a las formas de verificación del saber positivo, sino que responde a otras lógicas y a otros protocolos —otros «rituales de la verdad»—, más anclados en la propia vivencia y en el acto de «dar fe» de ella. En este orden de ideas, en el presente ensayo me interesa destacar que el desplazamiento de Sylvia Molloy del ámbito académico y del saber que lo organiza hacia una escritura literaria cargada de «valor biográfico» —esa noción que Arfuch toma de Bajtín, y que no necesariamente, o no solo, remite a la autobiografíasignifica también la apertura de una zona de contaminaciones respecto del tipo de «verdad» que entre ambos espacios se produce. Esta reflexión acompaña mi lectura de dos textos de la autora, Desarticulaciones y En breve cárcel, que, distantes en el marco de una larga trayectoria, no dejan de coincidir tanto en la honda implicación subjetiva de la escritura - esa forma de la «verdad» que el afecto inscribe en la letra de quien en ella se arriesga-, como en la incorporación de otros saberes 
semióticos y analíticos, literarios y culturales, que constituyen a la subjetividad crítica de quien no deja de exponerse en la escritura.

3 Tamara Kamenszain responde esta observación de Molloy con uno de los poemas que componen el libro El eco de mi madre de 2010, sobre el Alzheimer de su madre. Después de una cita de Molloy continúan los versos de Kamenszain: «Como mi madre que a veces me trata de usted/y yo me doy vuelta para ver quién soy,/la amiga de Sylvia que perdió el voseo/la desconoce hablándole de tú./ Correctas educadas casi pomposas/ estas rehenes del Alzheimer/ ponen a congelar la lengua materna/mientras nos despiden de su mundo sin palabras./ Sin embargo si te canto tu canción infantil/ la neurona del idisch se posa dulce sobre tus labios/y todo lo que nunca entendí en ese idioma/ lo repito con vos viejita, y me queda claro» (350). Agradezco a Julio Ramos la memoria de esta referencia.

4 Según afirma Molloy: «En un ya célebre ensayo sobre autobiografía y epitafios, Paul de Man privilegia la prosopopeya como figura autobiográfica por excelencia: "es la ficción de apostrofar una entidad ausente, fallecida o muda, con lo cual se postula la posibilidad de que esa entidad responda y se le confiere el poder de la palabra”». Y continúa: «No otra cosa por cierto hace el autobiógrafo: convoca a un yo caduco (a un yo que es ya no-yo) a quien le adjudica voz y máscara en el presente de la escritura» (2000b:234).

5 Respecto de la protagonista de En breve cárcel, afirma el narrador de la novela: «Volvió a esta ciudad para escribir pero no para escribir lo que está escribiendo. Pensó que lejos —_lejos de dónde? Se aleja de todos sus lugares- escribiría. Algo que le interesara, se decía, un ensayo sobre autobiografías ¿por qué no? Como no podía delimitar la suya, de manera coherente, leería autobiografías ajenas: por pura curiosidad y para crear pretextos que luego le permitirían reunirse consigo, dar una imagen única. Pero este texto, con sus venganzas, con sus recuerdos, con los personajes que ya han surgido, con las circunstancias que les pertenecen, ya está demasiado lastrado. Autobiografías: qué placer seguir a un yo, atender a sus mínimos meandros, detenerse en el pequeño detalle que, una y otra vez, lo constituye. Qué placer recordar que alguien se cortó el pelo y dejó de comer queso, qué placer recordar que alguien se guardó la lanzadera de su madre, inútil, a pesar de que se la necesitaba. Estas líneas no componen, y nunca quisieron componer una autobiografía: componen — querrían componer — una serie de violencias salteadas que le tocaron a ella, que también han tocado a otros» (Molloy, 1981:68).

6 Onetti, una ética de la angustia (2012) fue el último libro escrito por Sonia Mattalía —otra «rara» de la crítica literaria y cultural, formada en Argentina durante los años de la dictadura y residenciada en España a partir del obligado exilio— poco antes de perderse en los laberintos del Alzheimer. Escrito, ese sí, en estado de angustia - la angustia de quien quizá presentía ya los signos de esa enfermedad de la memoria que se pierde, que se va perdiendo con el vaciamiento subjetivo del habla- el libro comienza con el intento de tejer una semblanza «del más escurridizo de los escritores latinoamericanos», que en algún momento deviene memoriosa relación de encuentros e intervención irónica de la mujer que escribe de cara a la «verdad» de una vida. Esa mujer que desconoce las exigencias de una autoritas académica supuesta en el gesto a través del cual emerge en su discurso una decidida subjetividad autoral, como esa a través de la cual Molloy inscribe el vínculo entre lo que serían los nudos de una reflexión y los devenires vitales que los van puntuando desde el silencio al que los condena toda una tradición de pensamiento en Occidente: «Recuerdo la primera vez que lo vi, cuando se levantó para saludar a Juan Rulfo en el Cabildo de Canarias en 1979. Dos flacos altísimos, abrazados. Intercambiaron este diálogo: “Hola, Juan”, dijo uno. "Hola, Juan", contestó el otro. De vez en cuando Rulfo levantaba la cabeza y miraba a Dolly, único testigo asombrado y también mudo. “Mujer —le decía Rulfo— tú no sabes cuánto yo lo quiero a este hombre" y no miraba a Onetti al seguir hablando. "Por favor, dile a Juan que Juan lo quiere mucho". Juntos habían hecho un viaje bajo el volcán./ Recuerdo un mediodía de 1990 que se convirtió en tarde de fin de invierno: un encuentro en su casa en Madrid con Hugo Verani. Me tomó examen sobre mis lecturas, regañándome cuando no le gustaban algunos libros que, en aquel momento, me fascinaban y sobre los que él emitía juicios lapidarios. Salvó a algunos escritores, pocos, de la quema: Cristina Peri Rossi — “se juega la vida cuando escribe" - me dijo; entre los españoles, alabó a Antonio Muñoz Molina./ Le repetí su autorretrato de La vida breve: "Se llamaba Onetti, no sonreía, usaba anteojos, dejaba adivinar que solo podía ser simpático a mujeres fantasiosas o amigos íntimos", que él continuó con sorna: "No hubo preguntas, ningún deseo de intimar; Onetti me saludaba con monosílabos a los que infundía una imprecisa vibración de cariño, una burla impersonal”. 
Hizo un gesto despectivo, harto de esta cita reiterada por tantos de sus entrevistadores./ Recuerdo su larga figura recostada en una cama rodeada de montones de novelas policiales. Las cenizas flotantes de un cigarrillo infinito. Su enorme figura, sus ojos brillantes y atentos, su voz grave, burlona, sus juicios tajantes y definitivos cuando hablamos de intelectuales y letrados, su nostalgia infinita cuando se nombraba un Montevideo húmedo y nuestro.../(...). Me pidió explicaciones de por qué había escrito un libro sobre su obra y reiteró su escepticismo sobre los críticos repitiendo su difundido aserto: "Siempre dije que los críticos son como la muerte; a veces se demoran, pero fatalmente llegan"./ Saqué fuerzas del recuerdo de alguno de sus personajes femeninos y le conté la verdad. Me encontré con La vida breve en Montevideo, envuelta en papel de estraza y oculta bajo una montaña de novelas de segunda mano en un quiosquito de la Avenida 18 de Julio, en el año 1976. Onetti estaba prohibido en Uruguay pero yo tenía una cierta habilidad para lo clandestino. La leí tirada en la cama en un sótano de la calle Francisco Llambí en el barrio de Pocitos, en Montevideo; de vez en cuando miraba de reojo los zapatos de los transeúntes que pasaban por la vereda./ Había cruzado el charco huyendo de una Buenos Aires irrespirable y me reuní con Brausen en esa cueva que me alquilaban unos viejos inmigrantes. Ella, belga, doña Julia, me enseñó el poco francés que sé. Él, búlgaro, Yllia, me convidó más de una vez a comer rabo de vaca con pimienta. Consumían una damajuana diaria de vino tinto./ Conviví con la Queca, Miriam, Gertrudis, Stein, Ernesto, Mac Leod... y me convertí en Díaz Grey, Elena Sala, la violinista... Intercalé en el relato algunos énfasis literarios - Felisberto Hernández o Roberto Arlt-y terminé con una frase que me quedó redonda: “Santa María era mi destino"./ Onetti miró a Dolly, que escuchaba sentada en la cama. Unos segundos de pudor y una imperativa invitación: “Dolly, ella se va a quedar a almorzar”. Luego me preguntó “¿Eso lo puso en su libro, niña?”./ Le contesté que la crítica literaria no admite la autobiografía del crítico» (14-16).

\section{Referencias}

Agamben, G. (2005). El autor como gesto. En Profanaciones. Barcelona: Anagrama.

Arfuch, L. (2007). El espacio biográfico. Dilemas de la subjetividad contemporánea. Buenos Aires: Fondo de Cultura Económica.

Brindisi, J.M. (2016, 28 de febrero). Sylvia Molloy. «Crítica y narración son para mí proyectos paralelos en constante diálogo». Entrevista a Sylvia Molloy. La Nación. https://www.lanacion.com. ar/1874372-sylvia-molloy-critica-y-narracion-son-para-mi-proyectos-paralelos-en-constante-dialogo Foucault, M. (1986). La escritura de sí. http://d.scribd.com/docs/1vccwbbqlpjtr9pdpweo.pdf Girona Fibla, N. (2008). Rituales de la verdad. Mujeres y discursos en América Latina. México/París: Ritma 2/ADEHL. Kamenszain, T. (2012). La novela de la poesía. Poesía reunida. Buenos Aires: Adriana Hidalgo.

Masiello, F. (1985). En breve cárcel: la producción del sujeto. Hispamérica, 14(41), 103-112.

Mattalía, S. (2003). Máscaras suele vestir. Pasión y revuelta: escrituras de mujeres en América Latina. Madrid: Iberoamericana/Vervuert.

Mattalía, S. (2012). Onetti: una ética de la angustia. València: Universitat de València.

Molloy, S. (1981). En breve cárcel. Barcelona: Seix Barral.

Molloy, S. (1996). Acto de presencia. La escritura autobiográfica en Hispanoamérica. México: Fondo de Cultura Económica.

Molloy, S. (1997). Ficciones de la autobiografía. Vuelta, (253), 65-68.

Molloy, S. (2000a). Las letras de Borges y otros ensayos. Rosario: Beatriz Viterbo.

Molloy, S. (200ob). Cita y autofiguración en la obra de Borges. En Las letras de Borges y otros ensayos. Rosario: Beatriz Viterbo.

Molloy, S. (2002). El común olvido. Buenos Aires: Eterna Cadencia. 
Molloy, S. (2003). Varia imaginación. Rosario: Beatriz Viterbo.

Molloy, S. (2009). Desarticulaciones. En Guerrero, J. y Bouzaglio, N. (Comps.). Excesos del cuerpo. Ficciones de contagio y enfermedad en América Latina. Buenos Aires: Eterna Cadencia, 95-110.

Molloy, S. (2010). Desarticulaciones. Buenos Aires: Eterna Cadencia.

Molloy, S. (2016). Vivir entre lenguas. Buenos Aires: Eterna Cadencia.

Molloy, S. (2016, 15 de noviembre). Lo que me interesa no es escribir en contra de, sino tratar de ver el revés de las cosas. Entrevista a Sylvia Molloy. Télam. www.telam.com.ar/notas/201611/170500-sylvia-molloylibro-escritura-lectura.html

Piglia, R. (2012). Prólogo. En Molloy, S. En breve cárcel. Buenos Aires: Fondo de Cultura Económica.

Speranza, G. (1995). Primera persona. Conversaciones con quince narradores argentinos. Buenos Aires: Norma. 